\title{
KOGNITÍV, PSZICHODINAMIKUS ÉS RENDSZERSZEMLÉLETÚ MEGKÖZELÍTÉS - EGY ANOREXIA NERVOSÁBAN SZENVEDŐ SERDÜLÖ ESETE
}

\author{
Szerző: \\ Sáfrány Judit \\ Eszterházy Károly Egyetem
}

A szerző e-mail címe:

safrany12@gmail.com

\author{
Lektorok: \\ Mező Ferenc (Ph.D.) \\ Eszterházy Károly Egyetem \\ Mező Katalin (Ph.D.) \\ Debreceni Egyetem
}

és további két anonim lektor...

\section{Absztrakt}

Jelen esettanulmány egy 16 éves, anorexia nervosa-val diagnosztizált serdülő lány három szempontú pszichodiagnosztikus elemzését mutatja be. Új perspektívát jelent az OxIPO-modell alapján történő áttekintés.

Kulcsszavak: evészavar, anorexia nervosa, kognitív/tanuláselméleti szemlélet, pszichodinamikus szemlélet, rendszerszemlélet

Diszciplína: klinikai pszichológia, pszichiátria

\begin{abstract}
COGNITIVE, PSYCHODYNAMIC AND SYSTEM THEORY APPROACH - A CASE STUDY OF AN ADOLESCENT WITH ANOREXIA NERVOSA
\end{abstract}

Recent case study is intended to present a three-approached psychodiagnostic analysis of a 16-year-old girl with anorexia nervosa. Review with the OxIPO-model is a new perspective in the process.

Keywords: eating disorder, anorexia nervosa, cognitive/learning theory approach, psychodynamic approach, system theory approach

Disciplines: clinical psychology, psychiatry

Sáfrány Judit (2021): Kognitív, pszichodinamikus és rendszerszemléletű megközelítés egy anorexia nervosában szenvedő serdülő esete. OxIPO - interdiszciplináris tudományos folyóirat, 2021/1, 47-64. doi: 10.35405/OXIPO.2021.1.47 
A tanulmányban egy 16 éves serdülő lány esetének bemutatására kerül sor, akit - az anonim adatkezelésre vonatkozó etikai irányelveket figyelembe véve - Angelika néven kerül említésre.

Egy kórház gyermekpszichiátriai szakrendelését kereste fel az édesanya, s lánya fekvőbeteg osztályos kezelését követően kért pszichiátriai, pszichológiai segítséget. Kórosan alacsony testsúly (43 kg és 172,5 $\mathrm{cm})$, illetve különös evési szokásai, hangulati panaszai miatt került kórházba, ahonnan a család később saját felelősségére vitte haza Angelikát. Ezt követően szerettek volna ambuláns formában ellátást igényelni.

Tapasztalatom szerint az evészavarral diagnosztizált gyermekek és serdülők ellátását időnként félve vállalják a szakemberek. Saját szakmai gyakorlatomban észleltem, hogy az anorexia nervosa kórképe „egyre többször talál meg”, és az érintett személyekkel való közös munka egyre inkább elmélyíti érdeklődésem a témában. Mint ahogyan Angelika esetében is, megfigyelhettem, a segítő hozzáállás, a szakmai protokollok követése olykor kevés, falakba ütközik, és a terápiás miliő játszmák, ellenállások, áttételes érzelmek színhelyévé válik. Mindezek ellenére a kitartó, kölcsönösen aktív jelenlét, terápiás munka meggyőzött arról, érdemes részt venni az evészavarral küzdő személyek gyógyításában, hiszen jó eséllyel lehet változást elérni, a kliens életminőségét, interperszonális kapcsolatait, jövőképét, és még számos funkciót illetően.
Angelika esete tanulmányom megírásához gazdag kognitív, pszichodinamikus és rendszerszemléletű információkkal, összefüggésekkel szolgált. A szakmai protokollt és a hatékonyságvizsgálatok eredményeit figyelembe véve, mégis egyénre szabott diagnosztikus és terápiás tervre volt szükség. Már kezdetben motiváló erőként hatott, hogy Angelika aktív visszajelzést adott, korábbi pozitív és negatív tapasztalatait megosztotta a terápiás módszereket illetően. A kórházi kezelés során sokkal inkább passzív-agresszív hozzáállással, kifejezettebb noncompliance-szel viseltetett a segítő szakemberek iránt. Azt gondolom, végig kellett járnia ezt a megelőző utat is annak érdekében, hogy készen álljon a gyógyulásra.

\section{Tünetek és panaszok, exploráció}

Angelika kórosan fél az elhízástól, úgy érzi, kövér, vastag a combja, előnytelen a külseje, rondának tartja magát. Étkezésnél állandó alkudozás zajlik, arra törekszik, hogy minél kevesebbet kelljen ennie. Nem kér szinte semmiből, ha több alternatívát kínálnak fel neki, akkor sem választ. Hosszú az evésre szánt idő, mivel egy óráig kell neki könyörögni, hogy asztalhoz üljön, és még egy óra a rábeszélés, hogy egye meg az ételt. „Tápszerezem” mondja az anya, „csaképp, hogy nem teszem tisztába." Ezenkívül alig iszik, mert teltségérzetet okoz neki.

Aktuális testsúlya $43 \mathrm{~kg}$ (percentilis 3\%), testmagassága 172,5 cm (percentilis 90\%) 
- a kórházi osztályos kezelése óta nem gyarapodott. Testtömegindexe 14,45, ami a kórosan sovány kategóriába tartozó érték. Otthon nincs mérlegük, mert ha súlymérésnél $20 \mathrm{dkg}$ többlet is tapasztalható, pánikba esik, hiszen még mindig fogyni szeretne. Gyakran emlegeti, hogy „Annyira kövér vagyok, bogy lefolyok a székerôl." Időnként sír, édesanyja megéli a félelmet, nehogy szándékosan kárt tegyen magában. Tudja, hogy foglalkozik az öngyilkosság gondolatával, de sosem volt kísérlete, az édesanya úgy gondolja, hogy „okos lány, talán ilyet nem tenne”. További aktuális tünete a hajhullás, valamint a menstruáció több mint egy éve való elmaradása.

A kórház után magántanulói státuszba került Angelika, kortársaival ritkult a kapcsolattartása, sok időt tölt egyedül, szobájába zárkózva, de sosem volt igazán társaságkedvelő gyermek. Hetente kétszer vesz részt személyi edzésen, a sportedző fehérjeturmixok fogyasztását javasolja az edzésnél, amit Angelika elfogad. Naponta többször fut, hosszú sétákat tesz, kerékpározik, amiben az édesanya a partnere. Sport közben legalább kétszer nagyobb méretű pólót visel, mint valós ruhamérete. Fehérneműt a gyermekosztályon vásárolnak, nehéz megfelelő ruhát találni neki.

A pszichiátrián farmakoterápiában is részesült, anxiolitikumot kapott $(0,25 \mathrm{mg}$ Frontin), ezt továbbra is szedi, de nem tapasztalják, hogy segítene.

Aktuális problémaként azt nevezte meg, hogy „Nem szeretek enni, mert félek, hogy meghizok.” Kooperatív hozzáállást tanúsított, de igyekezett a minimumra csökkenteni az információtartalmat. Több kérdés kapcsán „diplomatikus” válaszadással tért ki. Példa erre az osztálytársakkal való kapcsolatára utaló érdeklődés, amire „Nem az én társaságom." válasz érkezett. A szabadidő eltöltésére vonatkozó kérdésnél szintén kimért választ adott: „Olvasni, zuenét hallgatni szeretek. Pont azokat szeretem csinálni, mint amiket egy átlagos serdülö." Jövőképként említette, hogy cukrász vagy dietetikus szeretne lenni. Meglepő volt a konkrét terv, hiszen az édesanya arról számolt be, hogy nincs kialakult jövőképe, még nem volt olyan hivatás, ami vonzó lett volna számára. A szakmaválasztás tükrözi aktuális beszúkültségét a táplálkozás, evési szokások témára.

\section{A tünetek kialakulásának története}

Megközelítőleg egy évvel korábban tapasztalták az első panaszokat, amikor egy hányással és hasmenéssel járó vírusfertőzésen ment keresztül Angelika. Fájt a gyomra, nem mert enni, nehogy kihányja az ételt. Az ennek következtében tapasztalt 1-2 kg-os testsúlycsökkenést sikerélményként élte meg. (A gimnázium elején $57 \mathrm{~kg}$ volt.) Elkezdte próbára tenni magát a súlyvesztés kapcsán, kíváncsi volt, mire képes - ezt utólag ismerte el. Édesanyja ezt észrevette, de nem tulajdonított neki különösebb jelentőséget. A környezetük ezzel szemben semmit sem észlelt. A következő változás az volt, hogy 
már nem étkezett együtt a családdal, mindig szobájába vitte be a ráerőszakolt élelmet. Egy idő után az édesanya „nyomozni” kezdett, és többek között kiderült, hogy az iskolába elvitt tízórait sem ette meg, hanem kidobta. Egy félév után már csak napi egy darab kekszet és legfeljebb egy kis dobozos joghurtot volt hajlandó elfogyasztani. Ekkor döntöttek úgy, hogy már nem képesek kézben tartani a helyzetet, aggódtak Angelika állapota miatt, és sürgősséggel gyermekpszichiátriai vizsgálatra, majd osztályos ellátásra került sor.

A kórházban töltött 83 nap alatt a szülők szétnéztek a szobájában, és több zsáknyi ételt találtak meg, különböző helyekre elrejtve. Ez az anya számára félelmetes volt, ekkor vált számára is világossá, hogy lánya beteg. A kórházi tartózkodásról annyit mesélt otthon Angelika, hogy nem mindig vette be a gyógyszerét, mert úgy érezte, semmit sem ér - utóbbit az édesanya is alátámasztotta. Nem mesélt terápiás ellátásról, az azonban ,idegesítette”, amikor a kezelőorvos jegyzetelt. Még nagyobb undort keltett benne, amikor „etették” az ápolók.

A kórházban többször elesett, egyszer fogmosás közben is rosszul lett, arccsontját beütötte, bőre megrepedt, véraláfutások voltak az arcán. Infúziót kapott, laboreredményei azonban mindig kifogástalanok voltak. Az édesanya végül úgy döntött, hogy a részletes felvilágosítás és az orvosi javaslat ellenére sem fogadják el a további hospitalizációt, és saját felelős- ségre hazavitték a kórházból Angelikát. Nem bízott az ellátást végző szakemberekben, nem tapasztalt javulást, ezért „,vette saját kezébe a dolgokat”. Ezt követően került sor a találkozásra. Az édesanya alapvető bizalmatlansága, hiperkritikussága (mind önmagával, mind környezetével szemben) egyértelműen azonosítható saját beszámolója, illetve szcénikus információk alapján is.

A találkozás idején az édesanya naponta változó, de kibontakozó betegségbelátásról számolt be, hiszen Angelika időnként emlegette, hogy „Ha majd meggyógyulok...". Kontroll nélkül azonban továbbra sem evett, és alig ivott, „Ott kell állni felette.”- mondta a szülő. „Zsaroljuk, hogy visszavisszük a kórházba.", erre még az otthon töltött 3. héten is szükség volt. Gyakran büntette magát „falási rohamai” miatt. Előfordult, hogy egy tábla csokit megevett egyszerre, ezt azonban önhánytatás nem követte. Kétségbeesett, megijedt, előhúzta bőröndjét, és kérte, „Anya, azonnal vigyél vissza a kórházba!’. Ezt a kérést azzal indokolta, hogy ott legalább felügyelet alatt van, és „nem tud zabálnı”. Ennek ellentmond, hogy többnyire azt hangoztatta, a kórházi kezelés óta rosszabbnak ítéli a helyzetet. Az édesanya szerint azonban „nem olyan depressziós azóta".

\section{Élettörténeti adatok}

Négyfős családban él Angelika, nővére néhány évvel idősebb, felsőfokú tanul- 
mányai végén jár, humán területen végezhető szakmát választott. (Viktória álnéven kerül említésre). Nagyszájú, karakán lány, Angelika ellentéte. Ô már elzárkózik húga problémájától, belefáradt az otthoni konfliktusokba. Kapcsolatuk egyébként is problémás, sosem voltak egymásra hangolódott testvérek. Viktória gyakran bántotta azzal, hogy kövér, sokat eszik, már egészen kisgyermekkorában, az óvodai évek alatt is. Angelika másik fájdalmas emléke, hogy nővére nem akarta elvinni iskolába, így hajnalban kellett kelnie édesanyjával. Édesanyja napi 8 órás munkarendben dolgozik. Édesapja 2-3 hetente egy hétvégét tölt otthon, mivel munkahelye külföldön található. Hét éve van távol családjától, az édesanya szerint „hétvégi apuka”, „nem olyan igazi apa”. A szülők kapcsolata nem tűnik kiegyensúlyozottnak: „Pont akekor ment el, amikor a legnagyobb szükeségün lett volna rá.” A családban a távoli munkavégzés indoklása egzisztenciális természetű. A nagycsaláddal ritkán találkoznak, azonban az anyai nagyszülőkkel szoros a kapcsolattartás, nyári szünetekben több időt is tölt náluk Angelika.

Angelika tanulmányaival sosem volt probléma, erôs 4-es tanuló, nagyon jó magaviseletű lány, csendes, „neki minden mindegy". Az édesanya úgy gondolja, sokat bántják az iskolában, talán történt is konkrét attrocitás, „a lányok gonoszak tudnak lenni.", de erről nincs információ. Felmerült az iskolaváltás, oda szeretnének átjelentkezni, ahol Angelika általános iskolai barátnői tanulnak. Azonban a tanév második felében sok hiányzást halmozott fel, amiket nem biztos, hogy pótolni tud, így felmerült az évismétlés szükségessége. Eddig minden szabadidejét tanulással töltötte - általában járkálva, szobájában elzárkózva olvas. Erős önbüntetési hajlama a tanulásban is megnyilvánul, egy-egy rosszabb osztályzat után órákig kínozza magát a könyv fölött.

Nagyon szeret sütni, cukrászkodni otthon, de nem eszik belőle. Az internethasználat nem köti le, szívesebben olvas. Gyakran jár antikváriumokba, betegségével kapcsolatos könyveket is vásárolt már. Emocionális önkifejezése szegényes, nem informatív. Nehezen mutatja ki az érzéseit, főként örömét. Egy korábbi tengerparti nyaralást sem tudott igazán élvezni, végig felöltözve, az árnyékban ücsörögve olvasott.

Szomatikus fejlődése zavartalanul zajlott. A várandósság és a szülés normális lefolyású volt, azonnal felsírt, életfunkciói rendben voltak, Apgar-értéke 9/10-es volt. Korai táplálásánál könnyen elfogadta az új ételeket, étvágya átlagosnak bizonyult. Három éves koráig anyatejjel is táplálták. Az édesanya hozzáfűzte, hogy első leánygyermekük után fiút vártak, amit Angelika is tud.

Mozgás- és beszédfejlődése a megszokott ütemú volt, megkésettséget sosem tapasztaltak. Intézményekbe, úgymint bölcsőde, óvoda, általános iskola, könnyen beilleszkedett, a szeparációt elfogadta. Óvodai élményeiből megmaradtak sérel- 
mei, például amikor édesapja egyszer nem ment érte időben, megfeledkezett róla a nap végén (1. táblázat). Barátkozásban nyitott, de nem kezdeményező.

Hallása ép, olvasáshoz szemüveget használ. Korábbi komolyabb betegség nem fordult elő, a fent említett vírusfertőzés az egyetlen megelőző, említésre méltó organikus panasz. Az első menstruációja 15 évesen volt, és nehezen fogadta el, hogy évtizedekig változatlan lesz a helyzet. Aktuálisan obstipációt tapasztal, széklete csak gyógyhatású készítmények mellett van. A családi anamnézisben pszichés megbetegedés nem fellelhető, azonban az édesanya az Angelikával való várandóssága alatt nagyobb súlyfelesleggel ren-delkezett, ami a szülést követően is problémát okozott neki. „Duci voltam.” mondja. Azóta diétázik, állandóan mozog: kocog, közösen kerékpároznak, kilométereket sétálnak együtt Angelikával. Az édesanyánál tapasztalt viselkedéses jegyek felvetik a felnőttkori evészavar gyanúját.

1. táblázat. Patobiogram. Forrás: Szerző".

\begin{tabular}{|c|c|c|}
\hline Életkor & Életesemény & Tünet \\
\hline \multirow[t]{2}{*}{ Óvodai évek } & $\begin{array}{l}\text { Nővére csúfolódása testsúlyára } \\
\text { és evési szokásaira vonatko- } \\
\text { zóan. }\end{array}$ & Nincs információ. \\
\hline & $\begin{array}{l}\text { Édesapa egy alkalommal nem } \\
\text { ment érte időben az óvodába. }\end{array}$ & Utólag sérelemként említi. \\
\hline $\begin{array}{c}\text { Kisiskolás } \\
\text { évek }\end{array}$ & $\begin{array}{l}\text { Nővére nem vitte magával } \\
\text { iskolába, emiatt hajnali indulás } \\
\text { édesanyával. }\end{array}$ & Testvérviszony megromlása. \\
\hline 9 éves & $\begin{array}{l}\text { Édesapa a családtól távol vállal } \\
\text { munkát. }\end{array}$ & Nincs információ. \\
\hline \multirow[t]{3}{*}{15 éves } & Első menstruáció & Elutasítás, aggodalom. \\
\hline & Vírusfertőzés & $\begin{array}{l}\text { Hányás, hasmenés, gyomorfájás, } \\
\text { evéssel szembeni averzió. } \\
\text { Egy-két kilogrammos } \\
\text { testsúlycsökkenés. }\end{array}$ \\
\hline & Családi nyaralás & $\begin{array}{l}\text { Izoláció, fürdőruha helyett teljes } \\
\text { öltözet. }\end{array}$ \\
\hline 15, 6 éves & Osztályfotózás & $\begin{array}{l}\text { Családdal való együtt étkezés } \\
\text { kerülése. Jelentôsen csökkent } \\
\text { ételmennyiség. Hangulati } \\
\text { problémák. }\end{array}$ \\
\hline 16 éves & Hospitalizáció & $\begin{array}{l}\text { Ujj tünet: mozgáskoordinációs } \\
\text { bizonytalanság. }\end{array}$ \\
\hline
\end{tabular}




\section{A pszichológiai kivizsgálás célja, klinikai kérdés}

A pszichológiai kivizsgálás elsődleges célja a tünetek etiológiájának megismerése, a betegségbelátás felmérése, aktuális pszichés állapotának valamint a terápiás motiváció feltérképezése. A diagnosztikus szakasz elvégzését követően a releváns, relapszusokat megelőző terápiás intervenciók meghatározása a fô célkitűzés.

A kivizsgálás során a következő klinikai kérdések megválaszolása az irányadó:

- Milyen intellektuális képességekkel rendelkezik Angelika? Állhat-e valamilyen területen tapasztalható kognitív képességbeli elmaradás az önmagával való elégedetlenség hátterében?

- Milyen a családi dinamika? Angelika hogyan éli meg jelenleg a családi kapcsolatokat?

- Milyen kötődési mintázattal rendelkezik?

- Szociális készségei milyen színvonalúak?

- A fő tüneti kép kiegészül-e depresszív vagy szorongásos tünetképzéssel?

\section{Pszichológiai vélemény három elmé- leti keretben}

Pszichodinamikus megközelités. Angelika vizsgálatra érkezése már determinálta a róla kialakult képet, hiszen a közvetítő szakember „művészlélekként” mutatta be őt nekem. A diagnosztikus szakaszban alkalmanként komoly nehézséget jelentett számomra, hogy koherensen értelmezzem a feltárt információkat, pszichés tartalmakat, hiszen egyre inkább átlagos személyiségkép és átlagos intellektuális képességek bontakoztak ki előttem. Angelika gondolatvilága sablonos, képzetáramlása sztereotíp, amit mind az exploráció, mind a tesztek eredményei alátámasztottak. A Metamorfózisok tesztjében korosztályához viszonyítva gyakoriak a vulgerválaszok, a Rorschach-jegyzőkönyv színvonala átlagos. Önmagában véve az „átlagember-felfedezés” nem jelent klinikai szintû problémát, nem táptalaja bármilyen személyiségbeli torzulásnak, azonban a szülei elvárása ütközik a valósággal, amit Angelika markánsan megél. A projektív tesztekben visszatérő motívum a „meg nem felelés" élménye, a produktivitás elmaradása, ami a serdülőkori identitásválságot elmélyíti, megküzdése azonban gátolt. Egyszerűségét, kisebbrendûségi komplexumát kivetíti a tesztekben, szinte „önéletrajzi vallomással” tölti meg a lapokat: egy szimbolikus nyelvezettel kommunikálja, mennyire vágyik az új felfedezésre, miszerint ő különlegesebb, mint kortársai. Minden alkalmat megragad a kitűnésre, a kiválóságra: erre utal a farajzok közül az „elvarázsolt fa”, aki eltér társaitól, mégis elfogadják. Fontos, ismétlődően visszatér utóbbi igénye is: az elfogadás. Identitáskrízisében ugyanis központi jelentőségű a külvilág visszajelzése, hiszen önértékelése a környezet függvénye, folyton változó. Önismereti 
deficite továbbmélyíti problémáját, azonosul a „beazonosíthatatlan fával”, az elvarázsolt család jelentéktelen „porszemével”, ezáltal önmagát érvényteleníti. Számára jelenleg az egyetlen lehetőség a kitűnésre „különleges” evési szokása, átlagtól eltérő testsúlya, „anorexiája”. Önmagával szemben szigorú követelményeket támaszt, meg kell felelnie a saját maga diktálta szabályoknak is, amiben kialakult testképzavara közvetít. A teljesítményelvárásokkal azonosul, integrálja őket, ugyanakkor szabadulna is tőlük, meneküléses ösztöne felszínre kerül a „madár” szimbólumával.

Szülei - elsősorban az édesanya - elégedetlensége frusztrációforrás Angelika számára is, aki aktuálisan nélkülözi a feltétel nélküli elfogadás, szeretet átélését. Erős bűntudattal, szorongással éli át, hogy szüleinek csalódást okoz, ezáltal önbüntető hajlama aktiválódik. A „mintagyerek” illúziója (Ábrahám, Árkovits, \& Gáti, 2008) megtörik, megbetegedéséért - ami családja számára megterhelő - önmagát teszi felelőssé, amit a percepcióban úgy képes kezelni, hogy elhárítással él, tagadja betegségét, a problémát. Tanult tehetetlenség állapotába kényszerül, kontrollvesztést él át, és „beteg fájával” együtt vállalja a szenvedést, passzívan tűri a kiszolgáltatottságot.

Már korai élményei között is megtalálható a „meg nem felelés” érzése, hiszen nővére érkezését követően szülei fiúgyermeket vártak, a „nem vagyok elég jó” megélésével indult élete. Korai, első tárgykapcsolata nem volt kielégítő minőségű, az anyai gondoskodás hiányos volt, fészekrajza rideg, bizonytalan, szorongással teli élményvilágot sugall. Már a várandósság alatt, majd születését követően édesanyja pszichés tünetekkel küzdött, nem tudta elfogadni önmagát, súlyfeleslege önértékelési gondokat okozott neki. Ez a probléma az újszülöttre, illetve a csecsemőre hangolódás akadályává válhatott, ami a „testi dialógus” sérült, félreértésekkel teli kialakulásához, működéséhez vezetett. Ezáltal vált Angelika vulnerábilissá a pszichoszomatikus tünetképzésre. Nehézségeket tapasztalva, illetve konfliktushelyzetekben fejlődése korábbi szakaszába visszaeshet, amiben az adott életkori időszak erogén zónája rögzült, ami esetében a csecsemőkor. Stresszhelyzetekben az általa preferált elhárító mechanizmus a regresszió, amit szülei megerősítenek. Az édesanya külön említést tesz az anamnézis során, hiszen úgy éli meg, lányát „tápszereznie” kell. Az etetés szükségessége, az étel elutasítása, illetve az evésre vonatkozó ösztönkésztetések uralása az orális fixációt támasztja alá, ami dinamikáját tekintve elvezethetett az anorexiás megbetegedésig (Onnis, 1993). Nem akar felnőni, a gyermekkor, mint érték jelenik meg, a szülők szeretete, elfogadása ehhez a korai életszakaszhoz kötött, mivel serdülő lányukkal több problémát élnek meg. Az anyának kritikus szerep jut gyermeke szükségleteinek megértésében és kielégítésében (Onnis, 1993), és Angelika édes- 
anyjánál határozottan jelen vannak egy kezeletlen, már krónikussá vált, talán szubklinikus evészavar tünetei. Angelika és édesanyja diádjában az étel, az étkezések központi szerepet kapnak, azonban az evési ösztön kielégítetlensége párhuzamban áll a kielégítetlen szeretet- és kötődésigénnyel. Angelika ezt a hiányt, frusztrációt bizonyos mértékben elaborálja: süteményeket készít, amikből azonban nem eszik, ellenáll a késztetésnek, amit önmaga idéz elő (saját választása ez a hobbi), ezáltal egyfajta autoagresszió is jellemzi őt.

Nárcisztikus - akár a serdülőkorban releváns - jegyek bontakoznak ki működésmódjában: a decentrálás hiánya, a saját kiválóság vágya, a szépség, a „gyönyörködtetés" igénye átszövi mindennapjait. Érzékletesen, többféle érzékszervi modalitásban fejezi ki vágyódásait, amik driveként működnek viselkedésében, mégis megválna tőlük, hiszen folyamatosan kielégítetlenül maradnak. A mércét a külvilág jelenti számára, bizonytalan identitása a visszajelzések függvénye, - ami szintén életkori vonás -, azonban szubjektív módon szűri ezeket az információkat, valóságpercepciója kóros romlást mutat. Mindazonáltal pszichés mûködésmódjában fellelhetőek egészséges, életkorilag releváns jegyek, úgymint a „hagyjanak békén" igénye, a kényelmesség, enerváltság, a csodavárás, a minél kisebb erőfeszítések megtétele, amit a projektív tesztek megoldásai mind tartalmilag, mind strukturálisan megerősítenek.
Erikson fejlődéselmélete alapján (Erikson, 2001) Angelika az identitás/szerepkonfúzió szakaszában tart: a hiányos önismereti tudás igazolja, hogy nem sikerült még teljesítenie életkori feladatát. A világ felfedezése, saját lehetőségeinek kipróbálása gátolt, nem éli meg a biztonságos hátteret, az anya nem tölti be holding-funkcióját a kudarcok, érzelmi sérülések esetén. Angelika kötődése labilis, felszínes, a kötődés tárgya gyakran változik, interperszonális kapcsolataiban ambivalens. Az ősbizalom zavart szenvedett nála, ami a befogadásra és elfogadásra való képesség alapja, az orális stádium funkcionálási módja. A kötődési probléma a Madárfészekrajz haloványságában, valamint a Rorschach teszt érzelmi alkalmazkodás, érzelmi kötődés felszólító jellegénél, valamint az anyával való gátolt kapcsolatkészség jelzésében is alátámasztást nyer.

$\mathrm{Az}$ intimitás elutasítása a kortárskapcsolatokban is felfedezhetô. Rossz szociális helyzetét racionalizálni igyekszik, „nem az én társaságom” -fogalmazza meg. Freud elmélete szerint a serdülőkorban feléledő nemiséggel szembeni ellenérzés az anorexia háttérmechanizmusaként hat (Ábrahám, Árkovits, és Gáti, 2008), amire hárítással, regresszióval reagál Angelika. Szexualitással szembeni averziója kifejezett, nem képes a témáról kommunikálni. A Rorschach teszt megoldásaiban a nőiséggel, a szexussal szembeni passzív attitűd, el nem köteleződés, mentális beszabályozottság, indu- 
lattalanítás látható. A biológiai változásokkal újjáéled a várandósság idején megélt csalódottság is, és ezt a csalódottságot már integrálja: nem tudott megfelelni szüleinek azzal, hogy nem fiúként jött a világra. Az anorexia a másodlagos nemi jellegeket elmossa a két nem között, ezáltal Angelika is megélhette, hogy közelebb került a feltétel nélküli elfogadáshoz. Az ödipális időszak jelentősége tetten érhető mûködésmódjában, az apához füződő viszonya felszínes, a serdülőkor viszont felkínálja a lehetôséget a korrektív élményre, azonban édesapja sem fizikailag, sem érzelmileg nem elérhető számára (Dare és Crowther, 1995).

Személyiségképében az első objektív, szcénikus és szubjektív információk passzív-agresszív működésmódra utaltak, noncompliance jellemezte, verbálisan alig hozzáférhető volt, érzelmeinek kifejezése, átélése differenciálatlan. Az édesanyával kapcsolatos első tapasztalatok erősen analógnak bizonyultak Angelika első benyomás szerinti megítélésével, mindketten kifejezett emocionális távolságot követeltek. Érzelmi hozzáférhetetlenségük, rigiditásuk védekező mechanizmusként értékelhető, a Metamorfózisok tesztben a taktilisan megközelíthetetlen „béka” és „kaktusz”, majd a tüskés csillagaival fenyegető „elvarázsolt fa” által ábrázolásra is kerül ez a fajta viszonyulásmód. A külvilággal szembeni bizalmatlanságuk indokolja ennek szükségességét, Angelika azonban már ambiva- lenciával kezeli ezt a múködésmódot, és a melegség érzetét keltő „pulcsi” a közelség- és szeretetigényt vetíti ki.

$\mathrm{Az}$ édesanya verbális és nonverbális kommunikációjának inkonzisztenciája megnehezíti a ráhangolódást, a valódi érzelmek percepcióját, ami már a korai anya-gyermek kapcsolatban az anyai tükröző funkcióban sérült (Gergely és Watson, 1998). Az érzelmileg szegényes légkör demotiváló számára, érzelmi elsivárosodást él meg. Angelika az érzelmek és belső élmények kontrollálatlansága miatt kétségbeesetten ragaszkodik valamiféle kontroll megszerzéséhez. Ezen a kontrollon keresztül személyisége védelemre tehet szert az elviselhetetlen és kezelhetetlen emóciókkal és az önmagával való elégedetlenséggel szemben (Dévald, 1993).

\section{Kognitiv/tanuláselméleti megközelités.}

Angelika tüneteinek indulása a viselkedésváltozás volt, elsôsorban a táplálkozási magatartás kapcsán, és az édesanya előtt fokozatosan rajzolódott ki az elhízástól való kóros félelem, majd a következményes szomatikus zavarok. Az egy évvel megelőző vírusfertőzés paradox módon sikerélményt hozott számára, megerősítést nyert a súlyvesztés, és a serdülőkori társas összehasonlítási igény központi tényezőjévé vált a testsúly, a külső megjelenés kérdése. Az édesanya evészavara szintén vulnerabilitási faktor, hiszen jutalomértékű volt mindkettőjük számára a közös sporttevékenység, az egészséges táplálko- 
zás preferálása. Magasabb küszöbérték jellemzi tehát az anyát a kóros és egészséges tartomány észlelésénél a testsúly és az egészséges életmód területén, saját valóságpercepciója is szubjektivizált, sérült. Ez megmagyarázza, miért történt relatív későn a klinikai szintű szimptómákhoz való szakmai segítségkérés.

A pszichodiagnosztikus szakasz tesztjei, kérdőívei az anorexia nervosa diagnózisát támasztották alá, a bulimiára utaló tendencia tüneteinek csupán saját perceptuális túlértékelése. A depresszió diagnózisa elvetésre került, hiszen az inadekvátság érzése, a diszfória, a kognitív beszűkülés, a negatív érzelmekre való fókuszálás az anorexia tüneteiben tipikus (Csenki, Németh és Pászthy, 2007).

Angelika alapvető frusztrációja saját átlagos képességeivel való szembesülése, ami a szülők - elsősorban az édesanya részéről szintén szenzitíven kezelt téma. Dependenciája a mások általi elfogadásra, elismerés igényére fókuszált (Rogers és Petri, 2001). Az autonómia megélésének sérülése a kérdőívekben is jelzett, teljesítményigénye fokozott. Az édesanya saját maladaptív sémája is lehet az átlagosság élménye, számára a sport jelent felemelkedési lehetőséget. Az anyával való kapcsolódási ponton túl Angelika számára betegségelőny a magántanulói státusz, ami kényelmesebb, valamint a rossz szociabilitása miatti kínos helyzeteket is elkerülheti ezáltal.
A kognitív konceptualizálás alapján az anorexia nervosa kialakulásának sémája Angelika betegségtörténetében logikusan végigvezethető. Az általános környezeti tényezőo, - melyek a tünetek kialakulásához vezettek - a családi diszfunkciók, a túlóvás, a merev külső és belső határok, valamint édesanyja evészavara. Egyéni vulnerabilitása a már említett „,csak átlagos vagyok" élményével indul, önértékelése ezáltal alacsony, perfekcionizmusa kifejezett.

A diétááashoz, súlyhoz, alakhoz kapcsolódó környezeti faktorok között szerepel édesanyja korábbi obesitása, és az azóta is fennálló evészavarra utaló - kezeletlen tünetek, nővére csúfolódása, valamint a serdülőkori szociális összehasonlítás megtapasztalása. Alapsémái aktiválódnak, megéli a „Haszontalan vagyok.”, „Csúnya vagyok.”, „Senki sem szeret.” élményét. Diszfunkcionális biedelmei felszínre kerülnek, és viselkedését befolyásolják: a gondolatok kognitív torzításokkal terheltek, önértékelését kórosan befolyásolják. Szigorú szabályokat fogalmaz meg önmagával szemben, próbál mindenben a maximumra törekedni, amiben azonban megéli képességbeli korlátait, frusztrálódik.

A serdülőkori krízis (biológiai változások, a nővé érés, felnőtté válás elutasítása, identitáskeresés, önismerethiány, leválási folyamatok), valamint a sqociokulturális tényezoók (karcsúságideál) a kritikus eseményeken keresztül (vírusfertőzés, fogyás, osztálykép) túlzott diétáási megszoritásokat, 
az evés fölötti kontroll gyakorlásának szükségességét hívják elő (Major, 2010).

Extrém önkontroll-igénye, alacsony önértékelése az evés korlátozására irányul, amin keresztül megéli a sikert, a kontroll megszerzésének élményét. Azonban a súlyvesztés az éhezési állapoton keresztül a kognitív képességek romlását idézi elő (csökkent koncentrációs készség, az érdeklődés beszúkülése), így válik az evés fölötti kontroll kudarcának veszélyévé, percepciójává, s ezáltal még inkább ösztönzi Angelikát az evés korlátozására. Fairburn elmélete az anorexia tüneteinek kognitív fenntartó tényezőire helytáll Angelika múködésmódjában (Fairburn, 1999).

Rendszerszemléletü megközelités. Angelika négyfős családban él, ami gyakorlatilag háromfősként funkcionál. Az édesanya már az első találkozásnál felhívja a figyelmet arra, hogy férje nem gyakorolja adekvát módon családfői, apai szerepét. Úgy éli meg, hogy magára hagyta a családot, kilépett a szövetségből. Az édesanya ugyan megfogalmazásában mindhármuk elhagyásáról beszél, mégis egyértelműen jelzett, hogy párkapcsolati konfliktus húzódhat meg a döntés hátterében. A házassági krízis a távmunka magyarázata mögé lett bújtatva, talán az érintettek sem akarnak szembesülni ezzel a ténnyel. Angelika édesapját érzelmileg sem integrálja a családi rendszerbe, de a mélyebb kötődési vágy fellelhető motivációs rendszerében. A Metamorfózisok tesztjében az alak/forma választással kifejezi a család stabilitásának megbillenését az édesapa jelenlétével, ezt a család belsô feszültségeként definiálja, saját teljesítményromlását is megtapasztalja ebben, ami szülei elégedetlenségét váltja ki, így elmélyíti az intrafamiliáris konfliktusokat. Bűntudattal terhelten éli meg ezt a tényt, és a tesztben elaborálni igyekszik feszültségét azáltal, hogy gondtalan életet, egészséget, egzisztenciát kíván családja számára. Feltételezhető, hogy a sütésekkel a családról is gondoskodik, ami egy támogató gesztus, szeretetkifejezés feléjük.

A családrajzok dinamikájában a családtagok kimenekülési vágya megfogalmazódik, mindenki izolált tevékenységet végez, perifériára vonul. Angelika is erre vágyik, amit a Metamorfózisok teszt „ház része" azonosulása és ellenazonosulása kapcsán ki is fejez. A család külvilág felé épített határai azonban nehezen átjárhatóak, ami a Fészekrajz struktúrájában is megjelenik.

A kinetikus család rajzán minden arcon mosoly látható, ami a család látszatharmóniára törekvését jeleníti meg. A családtagok intra- és interfamiliáris kapcsolatai távolságtartást, gátlást tükröznek.

Az „elvarázsolt fa” megközelíthetetlensége kiterjed mindannyiukra, és a madárfészek történetének „emberhiánya”, valamint a „beteg fa" félelme az emberektől általánosnak tekinthető Angelika család-jában. A változás, az apa munkahelyváltása már több évvel megelőzően történt, megoldás azonban - 
ami a feleség, ezáltal a család frusztrációját oldani tudná - nem született. A pszichoszomatikus családokra általánosan jellemző a változásra való képesség nehézsége (Onnis, 1993). Hibás családi copingok feltételezhetőek, azonban az intrafamiliáris játszmák megoldására nem képesek. Angelika pszichoszomatikus tünetei óta ezek a játszmák az étkezések köré szerveződnek. Ennek előnye számukra, hogy a valódi problémák megoldását elhalaszthatják a szülők, valamint kötelező kapcsolódási felületet jelent számukra.

A szakirodalom szerint (Szabó, Pászthy, és Túry, 2006) evészavarral diagnosztizált személyek családjában gyakori jelenség az apa perifériára kerülése. Ennek következtében az anya többletszerepet vállal, a családi funkciók teljességét magára veszi, köré szerveződnek a családtagok. Angelika családjában ugyanez a tendencia figyelhető meg, édesanyja túlvédő magatartást vesz magára, amivel gátolja lányai önállósági törekvéseit. Viktória ellent tudott állni ennek a nyomásnak, Angelika azonban passzív védekezéssel reagál. Az aktuális felállásban érzelmileg az anya, fizikailag az apa érhető el nehezebben, és a család már csak Angelika betegségére alapozva képes homeosztázisát megőrizni. A családban az autonómia károsodott, az önállóság-dependencia kritikusságát valamennyien érzékelik a nukleáris családban. A belső határok merevek, nehezen átjárhatóak, izoláció, kapcsolódási nehézségek, szegényes kommunikációs minták, érzelmi elszigetelődés figyelhető meg. A családi otthon kiüresedettsége, sivársága a Fészekrajzról markánsan leolvasható.

A családi egyensúly első megbillenése már Angelika világra érkezésekor bekövetkezett, amikor a családban a nemek aránya a nők javára tolódott el. Második gyermekként a „nem vagyok elég jó”, „nem felelek meg a szüleimnek” tapasztalata befolyásolja Angelika viselkedését. Nővérével ellentétben visszahúzódását, „mintagyerek” szerepét - az anorexia bekövetkezéséig - igyekezett megőrizni, ezáltal szülei szemében minél jobban helyt állni, minél kevesebb - további - problémát okozni. A kinetikus családban saját maga enkapszulációja is jelzi ennek megvalósulását, elvágyódik, elszigetelődik a családból, a hétköznapokból, és ez a távolítás visszatér a Fészekrajz illuzórikus történetszövésében, valamint a farajzok „pálmafájában” is.

Testvérével szemben erős rivalizálást, elutasítást tanúsít, azonban a pszichodiagnosztikus szakaszban felmerült a nővére iránti kapcsolódási igény, ami azonban sikertelen próbálkozás. A nagyobb lány életvitelét, értékrendjét Angelika kritikával illeti, egyfajta ellenazonosulást sugároz, mégis magában foglalja a nővér dolgai iránti érdeklődést. A sorozatos családi kudarcélmények következtében Angelika már nem fektet sok energiát a családi életbe (nővére megrajzolását szinte félbeszakítja a családrajzon), a perifériára húzódik, önmagát „enkapszulálja”. Az édesanya feltételezett evészavara, diszfunkcionális evési mintái, mint 
környezeti modell, valamint transzgenerációs hatásként (Mazzag, Pászthy és Túry, 2006) értelmezhetőek. Angelika evészavarában a családi diszfunkció tekinthető egy másik etiológiai tényezőnek.

$\mathrm{Az}$ érzelmek kommunikálása nem jellemző a családra, elfojtásos tendencia azono-sítható. A kommunikációhiány, az ener-giaáramlás gátoltsága a családrajzokban tetten érhető. Angelika tüneteire a családi homeosztázis fenntartásához van szükség, a kezelések megbeszélése, a közös döntési folyamatok minimális interakciót tesznek lehetővé. A hospitalizáció megtagadása tipikusan egy ilyen helyzet volt, ahol megélhették az összefogást, és bízni tudtak a család megtartó, „gyógyító” erejében.

Az alrendszerek működése a szülői és gyermeki szinteken összerendezetlen. A szülői alrendszerbe Viktória lépett fel, az édesanya - konfliktusaik ellenére is - vele tart fenn bizalmasabb kapcsolatot. Az édesapa egy saját alrendszert alkot, a családi konstellációban mellékszerepet tölt be. Angelika és édesanyja a sport által kapcsolódik alrendszerbe, míg Angelika és édesapja egy elméleti alrendszert alkothat vonásbeli hasonlóságaik alapján. Angelika édesapjához és apai nagymamájához érzi hasonlónak magát, mind külső megjelenését, mind belső tulajdonságait illetően. A családfa megrajzolásának feladata előrevetítette a családi kohézió hiányát, a szétesettséget, a nehéz kapcsolódást. A családi szerepekben az édesanya mint kiritikus és gondoskodó szülő szerepel, igyekszik ellenőrző funkciót ellátni, ezáltal a család egyensúlyát megőrizni. Az édesapa szerepe az egzisztenciális körülmények biztosítása, a gyermekek nevelését illetően ő nem veszi ki részét a feladatokból. A házaspárt érzelmi szakadék választja el egymástól, ami a távmunkában manifesztálódik. Kapcsolatuk felszínes, logisztikai jellegű, ami gyakorlatilag a lányaikkal való kapcsolatról is elmondható.

A kiterjedt családban elszigetelődés tapasztalható, a legtöbb intrafamiliáris kapcsolat protokollszerű, felszínes. Szeretnék a harmonikus és feszültség nélküli család látszatát fenntartani, ez azonban csak izoláció vagy a konfliktusok kerülése árán megvalósítható. Angelika egyedül anyai nagyszüleivel ápol valódi érzelmeken alapuló szeretetkapcsolatot, velük megélheti a feltétel nélküli elfogadás élményét. Énjének egészséges részeként a „szerethetőbb személyiség” birtoklását fejezi ki.

A rendszerszemlélet keretében értelmezve Angelikát és családját, fontos figyelembe venni az aktuális családi életciklust. A gyerekek életkorát tekintve a „serdülő gyermeket nevelő család" szakaszában (Komlósi, 1997) tartanak, ami a gyermekek önállósodásával, a családi fészekből való kirepülésükkel „fenyegető” időszak. Az édesanya számára ez különösen veszélyeztető gondolat, hiszen familiáris szerepei közül az anyai szerep dominál, ennek elvesztésével szereptelenné válik a rendszerben. Azonban 
nem indokolt az édesanya egyedüli megnevezése a pszichoszomatikus tünetképzés kapcsán. Sokkal inkább cirkuláris, mint lineáris okságról beszélhetünk, hiszen valamennyi családtag kölcsönhatásban van egymással, akár aktív, akár passzív módon.

A tünetképződés különböző megközelítéséseinek OxIPO-modell alapján történő értelmezési lehetőségét a 2. táblázat foglalja össze.

\section{Összefoglaló klinikai pszichológiai szakvélemény}

Angelika tüneti képének előterében az evési szokások megváltozása, csökkent étel- és folyadékbevitel, a fokozott sportaktivitás, az elhízás miatti kóros aggodalom, deprimált hangulat, negatív énkép, valamint szomatikus zavarok állnak. Az elvégzett vizsgálatok alapján az anorexia nervosa (F50.00) diagnózisa érte

2. táblázat. Attekintés az OxIPO-modell aspektusából (Mezó, 2011 alapján a Szerző)

\begin{tabular}{|c|c|c|c|c|}
\hline & Organizáció & Input & Process & Output \\
\hline $\begin{array}{l}\text { Kognitív/ } \\
\text { tanulás- } \\
\text { elméleti } \\
\text { megközelítés }\end{array}$ & $\begin{array}{l}\text { Családi és } \\
\text { társadalmi } \\
\text { minta a karcsú- } \\
\text { ság, ideális test- } \\
\text { alak tekinteté- } \\
\text { ben. }\end{array}$ & $\begin{array}{l}\text { Szorongást } \\
\text { keltô diszfunk- } \\
\text { cionális attitű- } \\
\text { dök, élmények } \\
\text { a saját testalak } \\
\text { kapcsán. }\end{array}$ & $\begin{array}{l}\text { Szorongásre- } \\
\text { dukció. }\end{array}$ & $\begin{array}{l}\text { A testsúly- } \\
\text { csökkentésre } \\
\text { tett kísérletek } \\
\text { hajszolása. }\end{array}$ \\
\hline $\begin{array}{l}\text { Pszicho- } \\
\text { dinamikus } \\
\text { megközelítés }\end{array}$ & $\begin{array}{l}\text { Az ödipális sza- } \\
\text { kasz korrektív } \\
\text { emocionális } \\
\text { élményét } \\
\text { akadályozó } \\
\text { környezet. }\end{array}$ & $\begin{array}{l}\text { Az átlagosság, } \\
\text { elhanyagolás } \\
\text { frusztráló } \\
\text { élménye. }\end{array}$ & $\begin{array}{l}\text { Elhárító mec- } \\
\text { hanizmus: } \\
\text { regresszió (a } \\
\text { fejlődési } \\
\text { folyamatok } \\
\text { lassítása) - a } \\
\text { saját test } \\
\text { aszexuálissá } \\
\text { tétele. }\end{array}$ & $\begin{array}{l}\text { Tünet: az } \\
\text { emocionális } \\
\text { elhanyagolás } \\
\text { szimbolikus } \\
\text { leképeződése } \\
\text {. }\end{array}$ \\
\hline $\begin{array}{l}\text { Rendszer- } \\
\text { szemléletü } \\
\text { megközelítés }\end{array}$ & $\begin{array}{l}\text { Diszfunkcionál } \\
\text { is családi min- } \\
\text { tázat. }\end{array}$ & $\begin{array}{l}\text { Emocionális és } \\
\text { fizikai } \\
\text { távolságok a } \\
\text { családon belül } \\
\text { (ingerszegény } \\
\text { környezet). }\end{array}$ & $\begin{array}{l}\text { Pszicho- } \\
\text { szomatikus } \\
\text { tünetképzés. }\end{array}$ & $\begin{array}{l}\mathrm{Az} \text { anorexia } \\
\text { nervosa } \\
\text { tünetei. }\end{array}$ \\
\hline
\end{tabular}


el a klinikai szintű diagnózist, az anxiodepresszív tünetek árnyalják a képet, de nem merítik ki a szükséges kritériumszintet.

Angelika alapvető karaktervonásai alapján mérsékelt társas ingereket preferál, introvertált személyiség, ami a serdülőkori változások kapcsán is igazolódni látszik. Életkorához viszonyítva rossz szociális státuszt tölt be, ez azonban számára másként jelenik meg, a környezeti nyomás ellenére sem vágyik aktívabb szociális szerepekre. Szociális nehézségeit azonban ő is megtapasztalja, konvencionálisan, de egocentrikus szemlélettel közelít a társas helyzetekhez. Emocionális kifejezőkészsége gátolt, érzelmi elsivárosodást, rigiditást él át, amit sikertelenség élményeként tapasztal meg, ezáltal kudarckerülő magatartást választ. Alapvetően konformista viszonyulásmódjában a serdülőkori lázadás az evéssel szembeni opponálásban valósul meg.

A serdülőkori krízis korai tárgykapcsolati élményeit aktiválja, nem tapasztal meg biztonságos talajt, családi bázist a világ felfedezéséhez, ami labilis kötődésekben, az interperszonális kapcsolatokban megélt ambivalenciában manifesztálódik. A kielégítő és biztonságos kötődést nélkülözi, amit belső bizonytalansággal, elhárító mechanizmusok aktiválásával kompenzál. Preferált elhárítása a regresszió, egy korábbi fejlődési zónába tér vissza, orális fixáció jellemzi. Pszichoszomatikus tünetképzésre hajlamos, a testi tünetekkel való kommuniká- ció markánsan jelen van pszichés működésmódjában. Önismereti igénye fokozott, de befelé fordulás nélkül nem képes új felfedezésekre önmagával kapcsolatban. A szexualitással szemben averziót él át, a nővé érés megtapasztalásának nehézsége az ödipális szakaszban is gyökerezik. Édesapjával érzelmi és fizikai távolságot tapasztal, mégis fokozott kapcsolódási igény jellemzi. Aktuális életkora lehetőséget nyújthatna a korábbi fejlődési feladat korrektív átélésére, azonban édesapja családból való kivonulása, perifériára kerülése nem ad teret a feladatnak. Aktuális életkori krízisét nem sikerült még abszolválnia, az identitáskeresés komoly kihívást jelent számára. Ebben a bizonytalan helyzetben egyensúlyát, énképének koherenciáját csak az evészavaron keresztül megélt különlegesség-élményben képes fenntartani.

A család érzelemszabályozási képességei sérültek, az autonómia megélése problémás. A szülők Angelikához való viszonyulása teljesítménycentrikus, nem közvetítik a feltétel nélküli elfogadást, szeretetet. Fokozott kapcsolódási igénye nem talál válaszra, ezért inkább ő is azonosul a család emocionális rigiditásával. A családi diszfunkciók ellenére nem képesek a változásra, a homeosztázist a családfó távollétével próbálják fenntartani. Angelika tünetképzése ezt az egyensúlyt szeretné valódi kötődésekké formálni, a család koherenciáját megteremteni, egy újfajta homeosztázissal. A családtagokkal szemben így egyfajta lojalitást vállal, valamint a 
kitűnni vágyás élményét adja meg önmaga számára a „különcség” kifejezésével. Átlagos intellektusával és egyéb átlagos képességeivel szembesülve frusztrációt él át, szülei elvárásainak nem képes megfelelni, azonban maladaptív megoldást választ az evészavar - tudattalan kiválasztásával.

Szorongásos, bűntudatos élmények jellemzik, valóságpercepciója torzított, a betegségbelátás hiányával saját újbóli kudarcélményét hárítja el. $\mathrm{Ha}$ az aktuálisan megélt kontrollt, sikerélményt elvennék tőle, bizonytalan énje veszélybe kerülne. Autoagresszió, önbüntetési hajlam jellemzi, amit kudarc esetén aktivál. Személyiségének azonban egészséges része is azonosítható, hiszen bizonyos mértékű elaborációra képes, valamint kedvező tulajdonságait is tudatosítani igyekszik. Kitartását helyezi a fókuszba, ami a terápiás szakasz prognózisa szempontjából központi tényező, előnyösen használva a terápia sikerét vetíti előre. Megfelelően motiváló környezetben, fokozatosan haladva, valamint stabil kötődési személy mellett pozitív jövőképet mutat.

\section{Irodalom}

Ábrahám, I., Árkovits, A., \& Gáti, Á. (2008). Az evészavarok pszichodinamikus megközelítése és terápiája. In Túry, F. \& Pászthy, B. (szerk.). Evészavarok és testképzavarok. Pro Die, Budapest, 197-210.

Csenki, L., K. Németh, M., \& Pászthy, B. (2007). A világjáték jellegzetességei a gyermek- és serdülőkori anorexia nervosában. Serdüló- és Gyermekpszichoterápia, 5. 25-44.

Dare, C., \& Crowther, C. (1995). Psychodynamic models of eating disorders. In: Szmukler, G., Dare, C., Treasure, J. (szerk.). Handbook of eating disorders. John Wiley \& Sons, Chichester, 125-139.

Dévald, P. (1993). Öndestruktivitás az evészavarokban. Pszichoanalitikus Gyermek- és Serdülőterápiás Intézet, Budapest.

Erikson, E. H. (2001). Gyermekkor es társadalom. Budapest, Osiris.

Fairburn, C. G., Shafran, R., \& Cooper, Z. (1999). A cognitive behavioural theory of anorexia nervosa. Behav. Res. Therapy 37, 1-13. DOI. 10.1016/s00057967(98)00102-8

Gergely, Gy., \& Watson, J.S. (1998). A szülői érzelmi tükrözés szociális biofeedback modellje: a csecsemô érzelmi öntudatra ébredése és az önkontroll kialakulása. Thalassa, 9. 56-105.

Komlósi, P. (1997). A család támogató és károsító hatásai a családtagok lelki egészségére. A család helyzete a társadalomban. In: Gerevich, J. (szerk.). Közösségi mentálhigiéné. Animula, Budapest, 13- 34.

Major, M. (2010). Bábból pillangóvá? Anorexiás kamaszlány kognitív viselkedésszempontú diagnosztikája. In: Perczel Forintos D. \& Kiss Zs. (szerk.). Higgyünk a szemünknek! ELTE Eötvös Kiadó, Budapest. 51-64. 
Mazzag, J., Pászthy, B., \& Túry, F. (2006). Rogers, R. L., \& Petri, T. A. (2001). Az evészavarok transzgenerációs átörö- Psychological correlates of anorexic and kítésének lehetőségei. Mentálbigiéné és bulimic symptomatology. J. Couns. Dev., Pszichoszomatika, 7, 269-286. DOI. 79, 178-187. DOI. 10.1002/j.155610.1556/Mentál.7.2006.4.1 $\underline{\text { 6676.2001.tb01958.x }}$

Mező, F. (2011). Tanulás: diagnosztika és fejlesztés az IPOO-modell alapján. $\mathrm{K}+\mathrm{F}$ Stúdió Kft., Debrecen.

Szabó L., Pászthy B., \& Túry F. (2006). Az apák szerepe az evészavarok családdinamikájában. Pszichoterápia, 15,

Onnis, L. (1993). A pszichoszomatikus 406-415.

zavarok rendszerszzemlélete. Családterápiás sorozat 3., Budapest. 